\title{
Efektivitas Implementasi Program Perumahan Bersubsidi Bagi Masyarakat Berpenghasilan Rendah Kota Pekanbaru (Studi Kasus : Kecamatan Tenayan Raya)
}

\author{
Effectiveness of Subsidied Housing Programs Implementation for Low-Income Communities \\ In Pekanbaru City (Case of Study: Tenayan Raya District)
}

\author{
Septia Fanny ${ }^{1}$, Firdaus ${ }^{1,}{ }^{*}$, Rona Muliana ${ }^{1}$ \\ ${ }_{1}$ Program Studi Perencanaan Wilayah dan Kota, Universitas Islam Riau, Jl. Kaharuddin Nasution No. 113 Pekanbaru, Riau, Indonesia
}

* Penulis korespondensi : agusfirdaus@eng.uir.ac.id

Tel.: +62-821-71-980-605; fax.:-

Diterima: Okt 21, 2020; Direvisi: Okt 26, 2020; Disetujui: Okt 28, 2020.

DOI: 10.25299/saintis.2020.vol20(02).5710

\section{Abstrak}

Untuk mengetahui tercapai atau tidaknya suatu tujuan program perlu dilakukan evaluasi terhadap implementasi program tersebut, baik pelaksanaan program maupun hasilnya. Evaluasi diperlukan untuk mengukur tingkat efektivitas mekanisme program dari pembiyaan dan apakah efektivitas bila dilihat dari hasil pembangunannya, disamping itu akan diketahui sejauhmana peran pemerintah melalui Kepnmen PUPR No.348/KPTS/M/2015, sebab untuk beberapa tahun kedepan kebijakan pembangunan perumahan MBR ini masih relavan dilaksanakan. Penelitian ini bertujuan untuk mengetahui tingkat efektivitas program. Pendekatan yang digunakan dalam peneltian ini adalah pendekatan deskriptif kualitatif yang didukung oleh data dari hasil kuesioner, wawancara, dan observasi lapangan, serta data dari kajian dokumen dan telaah pustaka. Perhitungan efektivitas dilakukan dengan melakukan pembobotan menggunakan skala Likert yang didasarkan pada kriteria efektivitas. Hasil penelitian menunjukkan secara umum efektifitas Implementasi Program Perumahan Bersubsidi bagi MBR mendapat nilai $80 \%$ yang berarti Efektif.

Kata Kunci: Efektivitas, Perumahan Bersubsidi, Masyarakat Berpenghasilan Rendah (MBR)

\begin{abstract}
To find out whether or not a program goal has been achieved, it is necessary to evaluate the implementation of the program, both the program's implementation and its results. Evaluation is needed to measure the effectiveness of the program mechanism of financing and whether the effectiveness when viewed from the results of its development, besides that it will be known to what extent the role of government through the Ministry of PUPR No. 348 / KPTS / M / 2015, because for the next few years the MBR housing development policy is still relavan implemented. This study aims to determine the level of effectiveness of the program. The approach used in this research is a quantitative and qualitative approach which is supported by data from the results of questionnaires, interviews and field observations, as well as data from document review and literature review. The effectiveness calculation is done by measuring the Likert scale based on the effectiveness criteria. The results shows that Effectiveness of Subsidied Housing Programs Implementation at a rate of $80 \%$ which mean genrally Effective.
\end{abstract}

Keywords: Effectiveness, Subsidized Housing, Low-Income Communities (LIC)

\section{PENDAHULUAN}

Rumah merupakan salah satu kebutuhan paling penting dalam kehidupan manusia, sama halnya dengan makanan dan pakaian. Rumah adalah salah satu kebutuhan paling penting dalam kehidupan manusia, khususnya dalam rumah tangga. Rumah memiliki arti penting bagi setiap keluarga karena rumah merupakan kebutuhan dasar tempat berkumpulnya keluarga. Pertumbuhan penduduk yang terus meningkat mengakibatkan permintaan atas rumah tidak seimbang dengan ketersediaan rumah yang menyebabkan terjadinya kekurangan rumah (backlog). Tingginya kebutuhan atas rumah mengakibatkan tingginya harga rumah. Hal ini akan menimbulkan hambatan bagi masyarakat yang berpenghasilan rendah (MBR) dalam mewujudkan impian untuk membeli rumah.

Persoalan perumahan dan permukiman bagi masyarakat berpenghasilan rendah bukan menyangkut pemecahan rancangan fisik, melainkan lebih berakar pada faktor sosial, ekonomi, dan politik yang saling berkaitan [1]. Tindakan pemerintah untuk mensejahterakan rakyat, dengan memberikan subsidi berupa rumah untuk masyarakat MBR diatur dalam berdasarkan Peraturan Menteri Pekerjaan Umum dan Perumahan Rakyat [2]. Pengadaan rumah untuk masyarakat yang berpenghasilan rendah memastikan bahwa masyarakat yang berpenghasilan rendah benarbenar mempunyai kemampuan untuk memiliki rumah. Bagi masyarakat berpenghasilan sangat rendah, faktor kesempatan (opportunity) bersifat penting sedangkan faktor identitas (identity) belum 
dipikirkan karena yang terpenting adalah memperoleh kerja guna mendapatkan keamanan (security) pada tahap selanjutnya [3]. UndangUndang memberikan tugas kepada pemerintah untuk terus berupaya meningkatkan pembangunan rumah bagi Masyarakat Berpenghasilan Rendah (MBR) [4] sehingga mereka dapat memiliki tempat tinggal yang layak dalam lingkungan perumahan yang sehat, aman, harmonis dan berkelanjutan.

Kebijakan program pembangunan sejuta rumah yang dicanangkan pemerintah melalui Kementerian Pekerjaan Umum dan Perumahan Rakyat (PUPR) bekerjasama dengan para pengembang perumahan (developer), lembaga keuangan (bank). Pembangunan Perumahan yang dikembangkan adalah rumah tipe 36 diperuntukkan bagi kelompok sasaran masyarakat yang penghasilan tetap atau tidak tetap yang berpenghasilan rendah. Akan tetapi dalam pelaksanaannya, ditemukan ketidaksingkronan dengan tujuan yang ditetapkan. Sebagai contoh adanya temuan rumah bersubsidi di Kelurahan Meteseh Kota Semarang yang hampir 30\% unit tidak dimiliki oleh kelompok sasaran, 9\% unit berstatus hak milik namun tidak dihuni, dan $6 \%$ dijadikan barang investasi [5]. Fakta ini menunjukkan adanya penyimpangan dalam pelaksanaan program, sehingga evaluasi terhadap efektifitas kebijakan sangat diperlukan sebagai upaya untuk menjamin pelaksanaan program tepat sasaran.

Peran pemerintah dan mekanisme program dalam penyediaan perumahan bagi masyarakat diatur berdasarkan Peraturan Menteri diantaranya pemberian kemudahan perizinan, penyediaan fasilitas, sarana dan utilitas (PSU), perintisan atau penyediaan Bank Tanah (Land Banking), penetapan zonasi untuk rumah sejahtera, penetapan zonasi untuk rumah sejahtera dan mekanisme pembiayaan [2].

Fasilitas yang diberikan pemerintah untuk program perumahan bersubsidi ini diberikan kepada masyarakat yang memenuhi persyaratan dan ketentuan untuk mendapatkan fasilitas kredit perumahan bersubsidi untuk MBR [6] yang telah ditetapkan adalah 1) WNI berusia 21 tahun atau telah menikah 2) Usia pemohon tidak melebihi 65 tahun pada saat kredit jatuh tempo 3) Pemohon maupun pasangan (suami/istri) tidak memiliki rumah dan belum pernah menerima subsidi pemerintah untuk pemilikan rumah. Dikecualikan 2 kali untuk TNI/Polri/PNS yang pindah tugas 4) Gaji/penghasilan pokok tidak melebihi 4 juta rupiah untuk rumah sejahtera tapak dan 7 juta rupiah untuk Rumah Sejahtera Susun, 5) Memiliki eKTP dan terdaftar di Dinas Kependudukan dan Catatan Sipil 6) Memiliki NPWP dan SPT tahunan PPh orang pribadi sesuai perundang-undangan yang berlaku, 7) Pengembang wajib terdaftar di Kementerian PUPR, 8) Spesifikasi rumah sesuai dengan peraturan pemerintah. Sedangkan persyaratan untuk mendapatkan subsidi diantaranya adalah kelompok yang belum pernah memiliki rumah, belum pernah menerima subsidi perumahan, mempunyai penghasilan dari tempat bekerja atau usaha yang didasarkan atas gaji pokok atau pendapatan pokok perbulan, yang terbagi dalam 3 kelompok sasaran sebagaimana diatur dalam Peraturan Menteri [7] tentang Pengadaan Perumahan dan Permukiman dengan dukungan fasilitas subsidi perumahan melalui KPR bersubsidi.

Melihat dari persyaratan dan ketentuan tersebut perlu dilakukan evaluasi apakah sudah efektif jika dilihat dari mekanisme pembiayaan dan tingkat efektivias hasil pembangunannya. Maka penelitian ini bertujuan untuk mengetahui sejauh mana tingkat efektivitas program perumahan bersubsidi bagi masyarakat berpenghasilan rendah (MBR) di Kota Pekanbaru.

\section{METODOLOGI}

Metode yang digunakan pada penelitian ini yaitu metode deskriptif dengan pendekatan kualitatif dan kuantitatif yang berupa penggambaran terhadap fenomena yang ada, melalui studi kepustakaan dengan data yang diukur dalam suatu skala numerik (angka) dengan menggunakan skala Likert untuk ukuran efektivitas. Pengambilan data dilakukan dengan menggunakan kuesioner kepada masyarakat dan wawancara personel dari sumber atau instansi terkait. Data yang diperoleh berupa jawaban dari responden masyarakat terhadap pernyataan yang diajukan. Teknik penyebaran kuesioner atau perolehan responden dalam penelitian ini diambil dari lokasi yakni di perumahan yang termasuk dalam kategori rumah sederhana bersubsidi di Kecamatan Tenayan Raya Kota Pekanbaru. Populasi dalam penelitian ini adalah kawasan perumahan sederhana bersubsidi yang menjadi objek penelitian perumahan MBR di Kecamatan Tenayan Raya Kota Pekanbaru. Sampel yang merupakan himpunan bagian dari unit populasi diambil dari jumlah rumah tangga masyarakat yang menghuni perumahan bersubsidi di Kecamatan Tenayan Raya Kota Pekanbaru berdasarkan data perumahan dari di Real Estate Indonesia (REI) Provinsi Riau. Teknik pengambilan sampel menggunakan metode purposive sampling atau judgement sampling.

Purposive sampling adalah salah satu teknik sampling non random dimana peneliti menentukan pengambilan sampel dengan cara menetapkan ciriciri khusus yang sesuai dengan tujuan penelitian sehingga diharapkan dapat menjawab permasalahan penelitian. Pengertian purposive sampling adalah teknik untuk menentukan sampel penelitian dengan beberapa pertimbangan tertentu berdasarkan kriteria-kriteria yang bertujuan agar data yang diperoleh nantinya bisa lebih representatif [8]. Hal ini dilakukan sesuai dengan kriteria subjek populasi yang ada di perumahan tipe 36 subsidi yang diprogramkan untuk masyarakat yang berpenghasilan rendah (MBR). 
Kriteria-kriteria penentuan sampel yang digunakan adalah 1) Perumahan program bersubsidi tipe 36 yang terdaftar di Real Estate Indonesia (REI) mulai tahun 2014 hingga tahun 2018; 2) Perumahan yang termasuk dalam program bersubsidi pemerintah tipe 36 yang tersebar di Kecamatan Tenayan Raya Kota Pekanbaru.

Skala Likert digunakan untuk mengukur sikap, pendapat dan persepsi sesesorang atau kelompok orang tentang fenomena sosial. Dengan skala Likert maka variabel yang akan diukur dijabarkan menjadi indikator variabel, kemudian indikator tersebut dijadikan sebagai titik tolak untuk menyusun item-item instrumen yang dapat berupa pertanyaan atau pernyataan [8].

Analisis yang digunakan adalah analisis skoring dengan menggunakan skala Likert. Analisis ini digunakan untuk menganalisis nilai efektivitas berdasarkan indikator yang telah ditentukan dalam penelitian ini terkait perumahan bersubsidi untuk MBR di Kecamatan Tenayan Raya. Data olahan untuk dimasukkan dalam analisis ini diperoleh dari responden yaitu masyarakat yang menjadi penghuni perumahan tersebut. Nantinya setelah diperoleh data tersebut akan dilakukan penggelompokkan data dan diolah sehingga menghasilkan kesimpulan apakah program ini telah terlaksana dengan baik atau tidaknya.

Tabel 1. Variabel Penelitian

\begin{tabular}{cl}
\hline \multicolumn{1}{c}{ Variabel } & \multicolumn{1}{c}{ SubVariabel } \\
\hline \multirow{3}{*}{ Peran Pemerintah } & $\begin{array}{l}\text { 1. Pemberian kemudahan } \\
\text { perizinan }\end{array}$ \\
& 2. Penyediaan PSU \\
& 3. Penyediaan Land Banking \\
& 4. Penetapan Zonasi \\
\hline \multirow{3}{*}{ Mekanisme Program } & 1. Mekanisme pembiayaan \\
& 2. Ketepatsasaran \\
& 3. Keterjangkauan \\
\hline \multirow{4}{*}{ Produk Perumahan } & 1. Standarisasi fisik rumah \\
& 2. Prasarana \\
& 3. Keberdayaan Masyarakat \\
& 4. Tingkat Penghunian \\
\hline
\end{tabular}

Kesimpulan yang dapat diperoleh berasal dari hasil hitungan efektivitas berdasarkan indikator yang tersedia. Apabila skor efektivitas hasil hitungan diperoleh angka besar dari 60\% maka program dinyatakan efektif namun bila skor hitungan yang diperoleh berada pada angka kurang dari $40 \%$ maka implementasi program perumahan bersubsidi bagi masyarakat berpenghasilan rendah ini dikatakan tidak efektif pelaksanaannya.

\section{HASIL DAN DISKUSI}

\section{Peran Pemerintah Dalam Program Perumahan Bersubsidi Bagi Masyarakat MBR}

\section{Pemberian Kemudahan Perizinan}

Pelaksanaan program pengembangan perumahan bersubsidi dilatarbelakangi oleh dua hal,

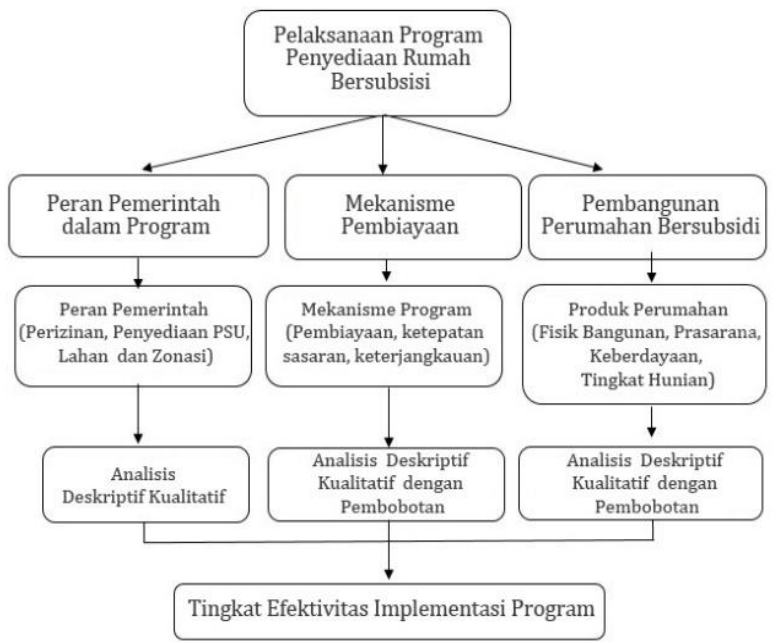

Gambar 2. Diagram Alir Penelitian

yang pertama yaitu rendahnya daya beli MBR untuk memiliki rumah subsidi melalui Kredit Pemilikan Rumah (KPR). Kedua, kurang kondusifnya regulasi yang terkait dengan pertanahan dan perizinan yang memberatkan pelaksanaan pembangunan perumahan khususnya bagi MBR. Permasalahan perizinan merupakan salah satu hambatan krusial yang mempengaruhi pelaksanaan program pembangunan perumahan bersubsidi bagi MBR selain masalah penyediaan tanah, pembiayaan, penyediaan prasarana dan sarana serta kelembagaan perumahan. Berdasarkan perhitungan Kemenko Perekonomian, penyelesaian perizinan pembangunan perumahan memerlukan waktu 753 hingga 916 hari dengan biaya sebesar 3,5 milyar rupiah untuk perumahan dalam kawasan seluas 5 Ha.

Sesuai dengan kewenangannya, Kementerian Pekerjaan Umum dan Perumahan Rakyat menetapkan target penyelesaian IMB paling cepat 3 (tiga) hari untuk bangunan gedung sederhana 1 lantai dan paling lama 30 (tiga puluh) hari untuk bangunan gedung tidak sederhana untuk kepentingan umum dan bangunan gedung khusus dengan ketinggian lebih dari 8 lantai [9]. Selain itu telah keluar paket kebijakan ekonomi ke 13 yang menyederhanakan proses perizinan dari 33 tahapan perizinan menjadi 11 tahapan perizinan, dan mempercepat proses dari 769-981 hari menjadi 44 hari, serta menurunkan biaya perizinan sebesar $70 \%$.

Pelaksanaan deregulasi perizinan tersebut belum berjalan efektif diberbagai daerah. Untuk penyelesaian perizinan masih membutuhkan waktu antara 12 hingga 60 hari untuk IMB biasa degan catatan segala persyaratan teknis sudah lengkap. Jumlah hari perizinan yang lain di luar IMB seperti izin lokasi, persetujuan gambar master plan, peil banjir, andalalin, Izin Pemanfaatan Tanah (IPT), siteplan dan pengukuran bidang tanah membutuhkan waktu rata-rata 30-60 hari. Akibat perizinan yang belum efektif, biaya perizinan masih mahal (10-20\%) dari total biaya pembangunan 
perumahan. Hal ini terjadi karena Pemda dibebani tanggungjawab untuk pelaksanaan peraturan perundangan (tata ruang, pertanahan, lingkungan hidup,dsb) dan perizinan masih menjadi sumber pendapatan asli daerah.

Pada perizinan IMB Peraturan Menteri [2] belum sepenuhnya dilaksanakan sebagai pedoman penyelenggaraan perizinan IMB di daerah. Hal ini terbukti dengan adanya persyaratan administrasi dan teknis yang berbeda dengan ketentuan di peraturan menteri tersebut. Dalam prakteknya, persyaratan administrasi yang dipersyaratkan di daerah lebih banyak dan rumit seperti adanya syarat fotocopy surat pemberitahuan pajak terhutang dan surat tanda terima setoran atau bukti pelunasan PBB tahun terakhir dan rekomendasi dari bank untuk tanah yang sedang digunakan. Dari segi prosedur, tahapan yang dijalankan lebih banyak karena diperlukan pemeriksaan dokumen administrasi dan teknis berjenjang serta peninjauan lapangan untuk memberikan rekomendasi teknis pembangunan perumahan. Jumlah unit pengelola perizinan yang berwenang dalam proses penerbitan IMB lebih banyak meliputi instansi kelurahan, kecamatan, PTSP, Dinas Tata Ruang/Kota/Bangunan, BPN dan pihak bank (jika diperlukan). Selain itu tidak ada perbedaan perlakuan perizinan dari aspek persyaratan, prosedur, waktu dan biaya antara IMB untuk pembangunan perumahan komersil dan perumahan untuk MBR. Dengan kondisi tersebut, banyak pengembang perumahan kurang berminat untuk melakukan pembangunan perumahan khusus MBR.

Dalam proses pemberian izin dari pemerintah kepada pihak developer perumahan melalui beberapa tahapan. Terlebih dahulu developer mengajukan proposal kepada pihak pemerintah kota/kabupaten yang nantinya proposal itu akan di lanjutkan ke pemerintah tingkat provinsi. Setelah proposal diterima oleh pemerintah provinsi sebagai hasil rekomendasi yang kemudian diserahkan kepada pemerintah kota/kabupaten kemudian dijadikan dasar bagi pemerintah kota/kabupaten untuk menerbitkan izin lokasi, barulah setelah itu developer mulai melakukan proses pembebasan lahan dari warga. Setelah pembebasan tanah tuntas, developer dapat mengajukan permohonan Hak Guna Bangunan (HGB).

Setelah HGB telah dikantongi, maka developer dapat melanjutkan ke tahap pra konstruksi. Dalam tahapan ini, ada sejumlah izin yang harus diajukan pengembang. Mulai dari Izin Peruntukan Penggunaan Tanah (IPPT), Masterplan (Rencana Induk), Kerangka Rencana Kota (KRK), dan Siteplan (Rencana Tapak). Kemudian Analisis Mengenai Dampak Lingkungan (AMDAL), Analisis Dampak Lalu Lintas (ANDAL LALIN), izin lingkungan kemudian barulah IMB.

Penyediaan Prasarana, Sarana dan Utilitas Umum
Pengembangan perumahan bersubsidi ini juga dilengkapi dengan prasarana, sarana dan utilias umum (PSU). Perumahan sederhana biasanya memiliki sarana dan prasarana yang masih minim [10]. Kelengkapan prasarana (tersedianya jaringan listrik dan air bersih) merupakan salah satu faktor yang sangat menentukan bagi penghuni perumahan dalam memilih lokasi perumahan yang ada di Pekanbaru [11]. PSU dalam program pengembangan perumahan bersubsidi untuk MBR ini mejadi bagian dari tugas pemerintah daerah atau kota. Pemberian bantuan PSU diutamakan bagi pelaku pembangunan berskala kecil [12]. Komponen bantuan PSU meliputi jalan, tempat pengolahan sampah dengan prinsip 3R (Reduce, Reuse, Recycle), dan jaringan sistem penyediaan air minum.

Peran pemerintah dalam hal menyediakan PSU terdapat tahapan yang harus dilalui oleh pihak pengembang diantaranya adalah mengajukan permohonan secara tertulis kepada Kementerian dengan tembusan kepada Pemerintah Daerah Kabupaten/Kota dan Pemerintah Provinsi. Kemudian Kementerian melakukan verifikasi dan menetapkan bantuan PSU kepada pengembang perumahan sesuai dengan ketentuan yang diatur dalam Peraturan Menteri. Setelah diverifikasi oleh Kementerian, keluarlah hasil verifikasi pra konstruksi yang meliputi pemeriksaan persyaratan administrasi dan teknis serta pemeriksaaan lokasi. Setelah verifikasi pra konstruksi dilakukan dan verifikasi telah diterima, Pemerintah Pusat dan Pemerintah Daerah sesuai dengan tugas dan wewenang melaksanakan pengawasan dan pengendalian pelaksanaan pembangunan fisik PSU. Pengawasan dan pengendalian dilakukan secara berjenjang mulai dari tingkat daerah kabupaten/kota, daerah provinsi sampai dengan Kementerian. Dalam pelaksanaan pembangunan fisik PSU dilakukan pengawasan lapangan oleh konsultan manajemen konstruksi, pengawas lapangan, direksi teknis, dan koordinator wilayah yang ditetapkan satuan kerja yang ditunjuk oleh Kementerian.

\section{Penyediaan Bank Tanah (Land Banking)}

Penyediaan Bank Tanah (Land Banking) untuk kawasan perumahan bersubsidi di Kecamatan Tenayan Raya karena daerah ini termasuk kawasan pinggiran kota yang cocok untuk dikembangkan sebagai kawasan perumahan [13]. Hal ini dikarenakan beberapa faktor seperti semakin padatnya kawasan dekat pusat kota sehingga sulit untuk mendapatkan lahan yang cukup luas untuk dikembangkan kawasan perumahan, kemudian harga lahan yang cukup tinggi di kawasan sekitar pusat kota sehingga menyulitkan developer untuk mengembangkan perumahan bersubsidi sebab harus mempertimbangkan harga jual rumah nantinya yang harus sesuai dengan ketetapan yang telah diberlakukan oleh pemerintah. Selain itu pemilihan kawasan pengembangan perumahan di 
pinggiran kota memberikan kesempatan untuk para pengembang dapat membangun perumahan di lahan yang luas dengan harga lahan yang bisa dijangkau agar bisa dipertimbangkan pula dengan harga jual rumah subsidi itu nantinya.

\section{Penetapan Zonasi}

Berdasarkan dokumen

Rencana Pembangunan Jangka Menengah Daerah (RPJMD) Kota Pekanbaru Tahun 2017-2022, luas lahan terbangun (built up areas) sekitar 24\% dari luas wilayah kota dan dimanfaatkan sebagai kawasan perumahan (sekitar 73\% dari luas areal terbangun), pusat pemerintahan, pendidikan, perdagangan, industri, militer, bandara, dan lain-lain. Areal belum terbangun (non built up areas) adalah sekitar 76\% dari luas wilayah kota saat ini yang merupakan kawasan lindung, perkebunan, semak belukar, dan hutan. Areal ini sebagian besar terdapat di wilayah utara kota (Rumbai dan Rumbai Pesisir), Tenayan Raya dan sekitarnya. Penetapan zonasi perumahan bersubsidi ini didasarkan pada ketentuan tersebut yang telah memberikan wewenang kepada pihak pengembang (developer) untuk melaksanakan pembangunan perumahan dengan kawasan Kecamatan Tenayan Raya yang juga merupakan Wilayah Pengembangan IV (WP IV) Kota Pekanbaru.

Kecamatan Tenayan Raya memiliki potensi untuk dikembangkan perumahan karena berada pada kawasan yang luas dan menghindari terjadinya kepadatan dan pemusatan ke tengah kota. Oleh sebab itu pengembangan kawasan untuk perumahan dilakukan kearah pinggiran kota agar kawasan pinggiran kota menjadi produktif dengan adanya pengembangan perumahan tersebut. Selain harga lahannya masih bisa di sesuaikan para developer agar harga jual rumah yang ditawarkan oleh developer bisa menyesuaikan dengan kebutuhan konsumen perumahan terutama masyarakat berpenghasilan rendah (MBR) tersebut.

\section{Analisis Efektivitas Mekanisme Program Perumahan Bersubsidi Bagi Masyarakat Berpenghasilan Rendah (MBR)}

Proporsi profil responden dalam penelitian ini adalah pengelompokkan responden berdasarkan jenis pekerjaan yang dimiliki oleh responden. Dari kuisioner yang disebarkan kepada 105 orang responden di lingkungan perumahan bersubsidi tipe 36 di Kecamatan Tenayan Raya. Mayoritas responden bekerja sebagai karyawan swasta yakni sebesar 45 orang atau 42,9 persen, bekerja di sektor informal 24 orang atau 22,9 persen dan sisanya adalah bekerja sebagai PNS dan wirausaha.

\section{Status Kepemilikan Rumah}

Status kepemilikan rumah MBR ini mayoritas adalah kepemilikan pribadi yakni 92,4 persen dari 105 responden, sisanya adalah mengontrak atau sewa yakni sekitar 7,6 persen.

\section{Mekanisme Pembiayaan Kemudahan Dalam Persyaratan dan Prosedur}

Pertanyaan yang diajukan kepada responden dalam penelitian ini tentang mekanisme pembiayaan, apakah terjadi kemudahan atau responden merasa kesulitan dengan beberapa syarat dan ketentuan untuk mendapatkan fasilitas kredit perumahan. Ternayata 86 persen atau sebanyak 90 kepala keluarga mengatakan bahwa persyaratan dan prosedur untuk mendapatkan fasilitas kredit perumahan bersubsidi ini dinilai mudah untuk dipenuhi. Sebanyak 90 kepala keluarga yang menyatakan bahwa dalam pemenuhan persyaratan untuk mendapatkan fasilitas kredit untuk pembelian rumah subsidi ini dinilai tidak menyulitkan atau 84,7 persen sangat mudah dalam memenuhi persyaratan dan prosedur perolehan perumahan bersubsidi.

\section{Kemudahan Dalam Sistem Pembayaran}

Kemudahan dalam system pemabayaran hasil dari survey menunjukkan 82,85 persen merasakan sangat mudah dan sisanya menyatakan merasa sulit. Persepsi penghuni yang berbeda itu mempunyai alasan bahwa calon konsumen yang tidak memiliki salah satu atau beberapa syarat yang harus dipenuhi tersebut agar proses administrasi dapat berlangsung dengan lancar.

Pada sistem keuangan yang mengatur sistem pembayaran perumahan subsidi ini telah diserahkan kepada pihak bank penyalur kredit perumahan. Sebagai bank penyalur kredit perumahan tentunya telah menerapkan aturan dalam pembayaran rumah subsidi terutama untuk sistem kredit atau cicilan. Berdasarkan jawaban dari responden menyatakan bahwa sistem pembayaran yang diterapkan pihak bank tidak menyulitkan bila berkas dan kelengkapan calon pembeli rumah telah memenuhi syarat dan aturan yang berlaku.

\section{Ketepatsasaran}

Ketepatan sasaran dilihat dari kesesuaian antara penerima perumahan bersubsidi dengan kriteria kelompok penerima berdasar teori. Kelompok sasaran/target penerima subsidi adalah keluarga/rumah tangga termasuk perorangan baik yang berpenghasilan tetap maupun tidak tetap, belum pernah memiliki rumah, belum pernah menerima subsidi perumahan dan memiliki keterbatasan akses permodalan dilembaga keuangan formal publik atau swasta [14]. Ketepatan sasaran program penerima subsidi perumahan yaitu rumah tangga yang belum pernah memiliki rumah dari hasil questioner ternyata frekuensi responden menjawab sebanyak 94,28 persen belum pernah memiliki rumah dan sisanya terdapat 5,71 persen atau sebanyak 6 responden menyatakan sudah pernah memiliki rumah. 
Sementara frekuensi responden menjawab belum pernah mendapatkan subsidi perumahan sebelum mengajukan diri untuk kepemilikan rumah subsidi ini yaitu 96,19. Selain itu terdapat 3,81 persen responden mengaku sudah pernah mendapatkan subsidi dalam bentuk lain dari pemerintah. Hal ini berarti masih ditemukan ketidaksesuaian dari ketentuan yang ditetapkan karena masih ditemukan konsumen perumahan bersubsidi untuk MBR yang sebelumnya sudah pernah mendapatkan subsidi dalam bentuk lain dari pemerintah.

Nominal tingkat pendapatan penghuni mempengaruhi fasilitas pemberian kredit. Dalam penelitian pendapatan calon konsumen perumahan minimal memiliki pendapatan , 4 juta rupiah setiap bulan. Dari hasil survey menyatakan penghuni yang pendapatannya diantara 3-4 juta rupiah berjumlah 53,3 persen, pendapatan antara 2-3 juta rupiah setiap bulan sebanyak 45,7 persen dan antara 1-2 juta rupiah perbulan sebanyak 1 persen.

Keterjangkauan harga jual rumah oleh penghuni yakni 78,1 persen berkemampuan untuk membeli, dengan ketentuan harga jual 130 juta, jangka waktu cicilan 15-20 tahun, uang muka KPR pertama sebesar 15 persen, cicilan bulanan yang harus dibayarkan adalah antara 650-850 ribu atau penghuni menyisihkan pendapatannya antara 1520 persen setiap bulannya. Jadi dari ketentuan tersebut sebanyak 90,5 persen penghuni rumah mampu mecicil rumah setiap bulannya.

\section{Analisis Efektivitas Hasil Pembangunan Dari Program Perumahan MBR}

\section{Standarisasi Fisik Rumah}

Kriteria fisik rumah subsidi berdasarkan Permenpera Republik Indonesia Nomor 25 Tahun 2011 misalnya memiliki luas lantai bangunan $36 \mathrm{~m}^{2}$, terdiri dari 2 kamar tidur disertai pencahayaan dan pengudaraan yang baik. Lebar minimum muka bangunan rumah 6 meter, dilengkapi dengan MCK dan dapur serta perumahan di dukung dengan PSU. Berdasarkan kriteria tersebut maka ternyata 81,52 persen hasil pembangunan sangat buah rumah layak huni.

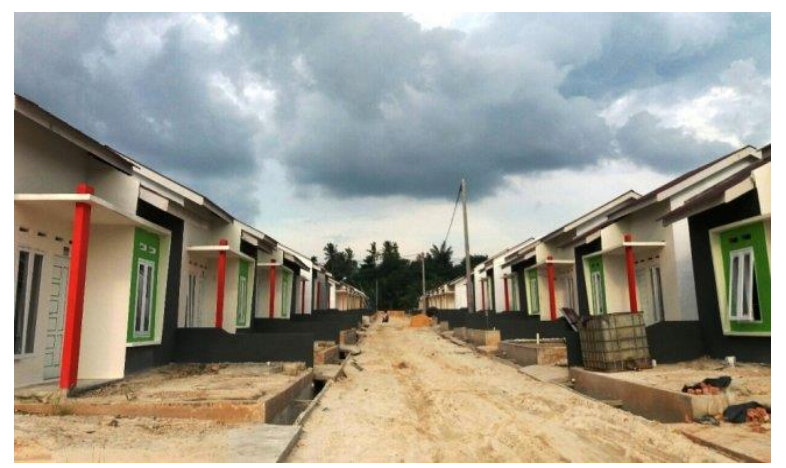

Gambar 2. Kondisi Fisik salah satu perumahan bersubsidi yang layak huni.

\section{Prasarana}

Implementasi pembangunan perumahan MBR ini telah dilengkapi dengan prasarana pendukung kegiatan lingkungan perumahan, misalnya jaringan jalan, drainase, jaringan listrik, sumber air bersih, sanitasi dan persampahan.

Tabel 2. Ceklist Kesesuaian Pembangunan Prasarana Perumahan Bersubsidi di Kecamatan Tenayan Raya Dengan Panduan PSU Perumahan Dan Permukiman Tahun 2013

\begin{tabular}{|c|c|c|c|}
\hline \multirow{2}{*}{$\begin{array}{c}\text { Jenis } \\
\text { Prasarana }\end{array}$} & \multirow{2}{*}{$\begin{array}{c}\text { Permen PUPR } \\
\text { No.03/PRT/M/2018 }\end{array}$} & \multicolumn{2}{|c|}{$\begin{array}{l}\text { Kesesuian } \\
\text { Lapangan }\end{array}$} \\
\hline & & $\begin{array}{l}\text { Sudah } \\
\text { Sesuai }\end{array}$ & $\begin{array}{l}\text { Belum } \\
\text { Sesuai }\end{array}$ \\
\hline Jalan & $\begin{array}{l}\text { Jalan dengan lebar } 3-4 \\
\text { meter ketebalan } 15 \mathrm{~cm} \\
\text { menggunakan jalan } \\
\text { beton semen atau } \\
\text { paving block dengan } \\
\text { ketebalan } 8 \mathrm{~cm}\end{array}$ & $\sqrt{ }$ & - \\
\hline \multirow[b]{2}{*}{ Drainase } & $\begin{array}{lr}\text { Saluran drainase } \\
\text { berupa saluran terbuka } \\
\text { dilengkapi dengan } \\
\text { bangunan pelengkap }\end{array}$ & $\sqrt{ }$ & - \\
\hline & $\begin{array}{lr}\text { Sistem drainase } \\
\text { dihubungkan dengan } \\
\text { badan badan air } \\
\text { (drainase } \\
\text { perkotaan/sungai) }\end{array}$ & - & $\sqrt{ }$ \\
\hline \multirow{2}{*}{ Air Bersih } & Tersedia jaringan PDAM & - & $\sqrt{ }$ \\
\hline & Pembuatan sumur bor & $\sqrt{ }$ & - \\
\hline \multirow{2}{*}{$\begin{array}{l}\text { Sanitasi \& } \\
\text { Persampah } \\
\text { an }\end{array}$} & $\begin{array}{lr}\text { Tersedia } & \text { limbah } \\
\text { komunal } & \text { yang } \\
\text { diperuntukkan } & \text { untuk } \\
20 \text { rumah } & \\
\end{array}$ & - & $\sqrt{ }$ \\
\hline & $\begin{array}{l}\text { Tersedia TPS } 3 \mathrm{R} \\
\text { terbuka dengan ukuran } \\
12 \times 6 \text { meter }\left(72 \mathrm{~m}^{2}\right)\end{array}$ & - & $\sqrt{ }$ \\
\hline
\end{tabular}

Sumber : Hasil Analisis

\section{Ukuran Efektivitas Program}

Dari seluruh indikator yang sudah dijelaskan pada sub bab sebelumnya, indikator-indikator tersebut kemudian di analisis dengan menggunakan interpretasi skor perhitungan dengan hasil sebagai berikut:

$$
\begin{aligned}
& Y=\text { skor tertinggi likert } \times \text { jumlah responden } \\
& X=\text { skor terendah likert } \times \text { jumlah responden }
\end{aligned}
$$

Sedangkan untuk kriteria interpretasi skor pada jawaban dalam hitungan persentase didasarkan pada interval berikut:

$$
\begin{aligned}
& \text { - } 80 \%-100 \%=\text { = sangat setuju } \\
& \text { - } 60 \%-79,99 \%=\text { setuju } \\
& \text { - } 40 \%-59,99 \% \text { = cukup setuju } \\
& \text { - } 20 \%-39,99 \%=\text { tidak setuju } \\
& \text { - } 0 \%-19,99 \% \text { = sangat tidak setuju }
\end{aligned}
$$


Kegiatan yang dilakukan secara efektif adalah kegiatan yang dalam proses pelaksanaanya menggunakan ketepatan antara harapan yang diinginkan dan hasil yang dicapai [15]. Sementara kegiatan tidak efektif adalah kegiatan yang mengalami kesenjangan antara harapan dan hasil yang ingin dicapai. Efektivitas merupakan ketepatan harapan, implementasi dan hasil yang dicapai. Dari hasil perhitungan yang dipersentasekan didapatkan bahwa secara keseluruhan instrumen yang diteliti menunjukkan nilai presentase sebagai berikut:

Subvariabel mekanisme pembiayaan dimasukkan dalam kriteria interpretasi skor sebesar 83,7 persen. Maka menyatakan bahwa subvariabel mekanisme pembiayaan perumahan bersubsidi yaitu sangat efektif. Untuk indikator dari

Tabel 3. Penilaian Efektivitas Program Perumahan Bersubsidi Bagi MBR

\begin{tabular}{|c|c|c|c|c|c|}
\hline Variabel & Sub Variabel & $\begin{array}{l}\text { Efektivitas } \\
\text { (\%) }\end{array}$ & $\begin{array}{l}\text { Rata-Rata } \\
\text { (\%) }\end{array}$ & $\begin{array}{l}\text { Rata-Rata } \\
\text { (\%) }\end{array}$ & $\begin{array}{l}\text { Efektivitas } \\
\text { Program }\end{array}$ \\
\hline \multirow{11}{*}{$\begin{array}{l}\text { Mekanisme } \\
\text { Program }\end{array}$} & Mekanisme Pembiayaan & & \multirow{3}{*}{$83,77 \%$} & \multirow{11}{*}{$80,74 \%$} & \multirow{25}{*}{$80 \%$} \\
\hline & Kemudahan Persyaratan dan Prosedur & $84,70 \%$ & & & \\
\hline & Kemudahan dalam Sistem Pembayaran & $82,85 \%$ & & & \\
\hline & Ketepatsasaran & & \multirow{5}{*}{ - } & & \\
\hline & Belum pernah memiliki rumah & - & & & \\
\hline & $\begin{array}{l}\text { Belum pernah mendapatkan subsidi } \\
\text { perumahan }\end{array}$ & - & & & \\
\hline & Jenis Pekerjaan & - & & & \\
\hline & Pendapatan & - & & & \\
\hline & Keterjangkauan & & & & \\
\hline & Harga Jual Mampu dipenuhi MBR & $76,19 \%$ & $77,71 \%$ & & \\
\hline & Kemampuan MBR membayar cicilan & $79,23 \%$ & & & \\
\hline \multirow{14}{*}{$\begin{array}{l}\text { Produk } \\
\text { Perumahan }\end{array}$} & Standar Fisik Rumah & & 01520 & \multirow{14}{*}{$79,62 \%$} & \\
\hline & Rumah sesuai standar layak huni & $81,52 \%$ & $81,5<\%$ & & \\
\hline & Prasarana & & \multirow{7}{*}{$73,01 \%$} & & \\
\hline & Jaringan Jalan & $76 \%$ & & & \\
\hline & Drainase & $76 \%$ & & & \\
\hline & Persampahan & $68,57 \%$ & & & \\
\hline & Air Bersih & $68,57 \%$ & & & \\
\hline & Sanitasi & $74,85 \%$ & & & \\
\hline & Jaringan Listrik & $74,09 \%$ & & & \\
\hline & Keberdayaan Masyarakat & & \multirow{3}{*}{$79,98 \%$} & & \\
\hline & $\begin{array}{l}\text { Rencana melakukan } \\
\text { rumah }\end{array}$ pemeliharaan & $81,30 \%$ & & & \\
\hline & $\begin{array}{l}\begin{array}{l}\text { Kemampuan } \\
\text { rumah }\end{array} \\
\end{array}$ & $78,66 \%$ & & & \\
\hline & Tingkat Hunian & & \multirow{2}{*}{$84 \%$} & & \\
\hline & Keamanan dan Kenyamanan & $84 \%$ & & & \\
\hline
\end{tabular}

\section{Sumber: Hasil Analisis}

ketepatsasaranan yang terdiri dari beberapa indikator yang menyatakan bahwa sudah atau pernah memiliki rumah, masih terdapat 5,71 persen penghuni mengatakan dirinya sudah pernah memiliki rumah sebelumnya dan sisanya 94,28 persen mengatakan belum pernah memiliki rumah sebelumnya. Hal ini berarti masih ditemukan ketidaksesuaian sasaran dari program perumahan bersubsidi ini. Kemudian untuk indikator sudah atau belum pernah menerima subsidi perumahan, sebanyak 96,19 persen penghuni perumahan belum pernah menerima subsidi perumahan sebelumnya dan masih ditemukan 3,8 persen yang mengaku sudah pernah mendapatkan subsidi perumahan sebelum mengurus kepemilikan rumah subsidi yang sekarang dihuni.

Pada indikator jenis pekerjaan yang berkaitan dengan pendapatan, menurut ketentuan dan syarat untuk bisa memiliki rumah bersubsidi ini tidak dibedakan jenis pekerjaan bagi calon pembeli rumah 
baik yang bekerja di sektor formal maupun informal. Sejauh ini berdasarkan hasil observasi dan kuisioner, pemilik rumah bersubsidi ini yang paling banyak menjadi konsumen perumahan bersubsidi adalah orang yang bekerja menjadi karyawan swasta yaitu sebesar 41 persen. Pada indikator pendapatan, tidak ditemukan responden perumahan bersubsidi ini yang memiliki pendapatan 4 juta rupiah. Ini artinya dari indikator pendapatan sudah sesuai dengan ketentuan yang telah ditetapkan.

Subvariabel keterjangkauan dimasukkan dalam kriteria intrepretasi skor sebesar 77,71 persen. Maka menyatakan bahwa subvariabel keterjangkauan MBR dalam memenuhi harga rumah yang ditetapkan sudah efektif. Untuk subvariabel standar fisik rumah dimasukkan dalam kriteria interpretasi skor sebesar 81,52 persen. Maka menyatakan bahwa dalam subvariabel standar fisik rumah dengan kesesuaian dilapangan sudah dilaksanakan dengan sangat efektif.

Hasil survey diperoleh bahwa subvariabel prasarana dimasukkan dalam kriteria interpretasi skor sebesar 73,01 persen. Maka menyatakan bahwa dalam subvariabel prasarana yang diterapkan di lingkungan perumahan subsidi dinilai efektif. subvariabel keberdayan masayarakat dimasukkan dalam kriteria interpretasi skor sebesar 79,98 persen dinyatakan efektif, selanjutnya bahwa subvariabel tingkat hunian dimasukkan dalam kriteria interpretasi skor sebesar 84 persen dinyatakan sangat efektif.

Berdasarkan hasil olahan data dengan perhitungan skala Likert maka diperoleh jawaban tingkat efektivitas program pembangunan perumahan bersubsidi bagi masyarakat berpenghasilan rendah (MBR) yaitu sebesar 80 persen.

Setelah menghitung efektivitas secara keseluruhan indikator, maka diketahui bahwa nilai efektifitas program perumahan bersubsidi tersebut berada pada nilai $80 \%$. Kemudian hasil bisa dilihat berdasarkan kriteria interpretasi dalam persen tersebut [16].

\section{Tingkat Efektivitas Implementasi Program Perumahan MBR}

Perolehan skor dari penelitian ini berada pada angka 61\%-80\%. Hal ini menyatakan bahwa skor penelitian ini untuk membuktikan bahwa program perumahan bersubsidi bagi masayarakat berpenghasilan rendah (MBR) di Kecamatan Tenayan Raya Kota Pekanbaru sudah berlangsung secara efektif. karena program ini memberikan kemudahan bagi MBR untuk dapat memiliki rumah dengan harga terjangkau.

\section{KESIMPULAN}

Berdasarkan hasil analisis yang dilakukan maka didapatkan kesimpulan mengenai efektivitas implementasi program perumahan bersubsidi bagi
Tabel 4. Tabel Kriteria Interpretasi Skor Efektivitas

\begin{tabular}{ccc}
\hline No & Kriteria Interpretasi & Kategori \\
\hline 1 & $81 \%-100 \%$ & Sangat Efektif \\
\hline 2 & $61 \%-80 \%$ & Efektif \\
\hline 3 & $41 \%-60 \%$ & Cukukp efektif \\
\hline 4 & $21 \%-40 \%$ & Kurang efektif \\
\hline 5 & $0 \%-20 \%$ & $\begin{array}{c}\text { Sangat Kurang } \\
\text { Efektif }\end{array}$ \\
\hline
\end{tabular}

Sumber: Sugiyono (2012)

masyarakat MBR di Kecamatan Tenayan Raya Kota Pekanbaru antara lain yaitu peran pemerintah daerah sepenuhnya sebagaimana diatur dalam peremn PUPR selaku pihak regulator yang terlibat dalam 4 pilar pembangunan perumahan, dalam hal ini berwenang dalam mengurus perizinan lokasi (IMB), penyediaan prasarana sarana dan utilitas umum (PSU), perintisan (penyediaan) land banking, dan zonasi perumahan. Berdasarkan hasil penelitian didapat pada masing-masing instrumen variabel efektivitas dengan subvariabel mekanisme pembiayaan, keterjangkauan, standar fisik dan tingkat hunian menunjukkan hasil efektif pada tingkat efektivitas 80 persen. Namun masih ditemukan jumlah kecil penghuni telah pernah memiliki dan telah pernah mendapatkan subsidi perumahan sebelumnya.

\section{REFERENSI}

[1] Madhu S. Mishra, Bibliography on Management of Rural Development. Calcutta: Publications Division, Indian Institute of Management, Calcutta, 1983.

[2] Kementerian PUPR, "Peraturan Menteri Pekerjaan Umum dan Perumahan Rakyat No. 21/PRT/M/2016 tentang kemudahan dan/atau bantuan perolehan rumah bagi masyarakat." 2016.

[3] B. Panudju, Pengadaan perumahan kota dengan peran serta masyarakat berpenghasilan rendah / Bambang Panudju, 1st ed. Bandung: Alumni, 1999.

[4] UU Republik Indonesia, Undang-Undang Nomor 1 Tahun 2011 tentang Perumahan dan Kawasan Permukiman. 2011.

[5] D. D. Siswanti, "Pengendalian Kepemilikan RSH Subsidi di Kelurahan Meteseh Kota Semarang," J. Pembang. Wil. Kota, vol. 9, no. 2, p. 194, 2013.

[6] Kementerian PUPR, "Rencana Strategis Direktorat Jendral Pembiayaan Perumahan Kementerian Pekerjaan Umum dan Perumahan Rakyat Tahun 2015-2019." 2015.

[7] Kementerian PUPR, "Peraturan Menteri Negara Perumahan Rakyat Nomor 03/PERMEN/M/2007 tentang Pengadaan Perumahan dan Permukiman dengan dukungan fasilitas subsidi perumahan melalui KPR bersubsidi." 2007.

[8] Sugiyono, Metode Penelitian Kuantitatif 
Kualitatif dan $R \& B$, 13th ed. Bandung: Alfabeta, 2012.

[9] Kementerian PUPR, "Peraturan Menteri Pekerjaan Umum dan Perumahan Rakyat No.05/PRT/M/2015 tentang Izin Mendirikan Bangunan (IMB) gedung." 2015.

[10] T. Adimagistra and B. Pigawati, "Evaluasi Penyediaan Sarana Dan Prasarana Di Perumahan Puri Dinar Mas Semarang," J. Pengemb. Kota, vol. 4, no. 1, p. 58, 2016.

[11] F. Asteriani, "Preferensi Penghuni Perumahan Di Kota Pekanbaru Dalam Menentukan Lokasi Perumahan," J. Ekon. Pembang. Kaji. Masal. Ekon. dan Pembang., vol. 12, no. 1, p. 77, 2011.

[12] Kementerian PUPR, "Peraturan Menteri PUPR Nomor 38/PRT/M/2015 tentang Bantuan Prasarana, Sarana dan Utilitas Umum untuk Perumahan Umum." 2015.

[13] Pemerintah Kota Pekanbaru, "Draft Rencana Tata Ruang Wilayah Kota Pekanbaru 20142034." 2014.

[14] N. A. Innayah, "Tipologi Kredit Mikro Perumahan di kota Semarang," Universitas Diponegoro, 2007.

[15] Makmur, Efektivitas Kebijakan Kelembagaan Pengawasan. Bandung: Refika Aditama, 2011.

[16] Gilang Ramadhan, "Efektivitas Program Perumahan Bersubsidi Pada Bank Tabungan Negara Syariah Cabang Surakarta," Institut Agama Islam Negeri Surakarta, 2017. 